\title{
Who are the disciples? Identity perceptions about millennials and the church
}

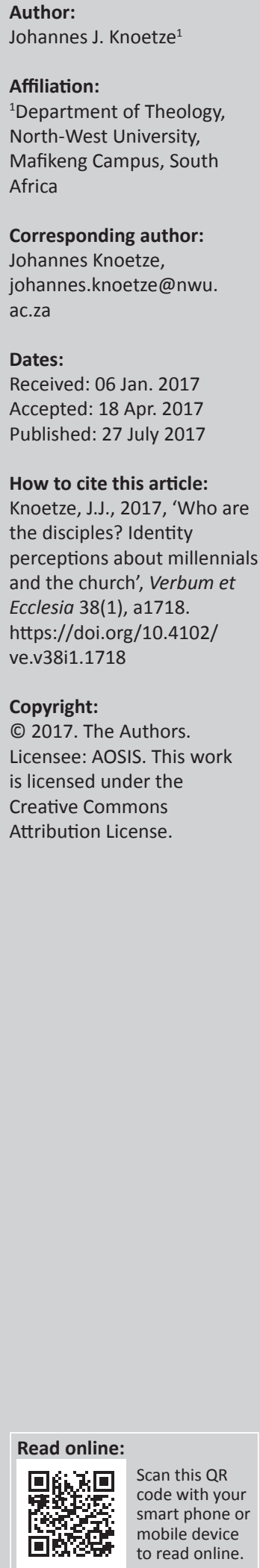

This article specifically focusses on understanding the discipleship process of the millennial generation (15-35 years of age) in Africa. The millennial generation is the largest population group in Africa, with more than 200 million individuals in Africa. Focussing on developing a disciple identity with African millennials from a missional ecclesiology, the question attended to is: What is the church's perception of the identity of these African millennials and how can the church disciple them? Discipleship is understood as to engage with people to discover their true identity and vocation in God. Discipleship takes place on three different levels according to the modern worldview: the spiritual world (Gospel-as-word), the seen world (Gospel-as-deed) and the excluded middle (Gospel-as-sign). These distinctions have, for example, the implication that discipling is located not only at the church but also in the world. Millennials are motivated as much by their personal relationships and human connections as they are by the influences of their technological skills, social media and group pressure. It is observed in this article that millennials are currently discipling the world in different ways. Therefore, four suggested steps are discussed for the churches to involve millennials in their discipleship programmes.

Intradisciplinary and/or interdisciplinary implications: It is believed that this article has definite intra- and interdisciplinary implications. Although this article is written from a missiological departure, it also covers other theological disciplines like Practical Theology and Youth work. It also includes articles from communications and sociology and would make valuable contributions to the field of, especially, sociology as well as anthropology.

\section{Introduction}

This article focusses on developing a disciple identity with African millennials ${ }^{1}$ from a missional ${ }^{2}$ ecclesiology. A literature study is conducted to attend to the question: What are the identity perceptions of the church in viewing the African millennials and discipleship? Identity is not only a personal or permanent property or characteristic that is always the same but identity is always developing or in development. It may even imply that a person has different identities in different contexts. South African millennials can be white millennials, black millennials, African traditional millennials, global age millennials, Christian millennials, et cetera. Nel (2000:21-25) indicates that God is finished creating but he is never finished with his creation. He continues to describe the church as an agogic (ever changing) community. From a Christian viewpoint, the church as an agent of God is an important contributor to identity formation amongst the millennials who in a natural way experience a continuous change. Focussing on (South) African millennials, Du Toit (2004:33) indicates that an African is identified by the community and the place she or he occupies in the community through relationships. In Africa, identity is not primarily determined through individualistic assets. It is a matter of 'I participate, therefore I am'. Best described by the Ubuntu principle of 'I am only because we are, and since we are, therefore I am' (Du Toit 2004:33). Descartes' famous statement 'I think therefore I am' may best describe the individualistic understanding of identity in a modern (South) Africa. However, from a Biblical humanity as well as discipleship perspective, this article wants to define identity with the statement: I am and you are, because he (God) is.

Linking the large number of millennials in (South) Africa which focusses on identity and discipleship puts some new questions on the table (Counted \& Arawole 2016:2). Especially because millennials are setting the trend in the world communication and economy as founders of social media

1.Discussing Africa's millennials, this article follows a homogenising system in which there is no room for an in-depth discussion of the unique and complex religious system and characteristics of each group of people (cf. Adogbo 2005:76); millennials are viewed as those between the ages of 15 and 34 years, unless indicated otherwise.

2.'Missional is simply an adjective denoting something that is related to or characterized by mission, or has the qualities, attributes or dynamics of mission' (Wright 2006:24). 
companies like You-Tube, Facebook and others. From the church, the questions that arise are: Who is discipling who? Have the millennials become the disciple-makers? What kind of influence does technology and social media have on identity and identity formation, not only of the millennials but also of the church? In an attempt to answer these questions, attention will be given to an understanding of identity, discipleship and millennials, to get a perspective on the question: What kind of person am I going to be? This question is asked to become aware of the different identity perceptions that are used in viewing the millennials and the church.

\section{Identity}

As argued above, identity has to do with the way we think about ourselves and how we relate to the world or society we live in. Identity can be understood according to self-definition and/or as a particular form of social representation that mediates the relationship between the individual and the communal world. Identity helps to inscribe a person in a social environment to relate to other people's positions. From a Christian perspective, it is in this regard that baptism as a sacrament, where people are baptised in Christ and into the church as his body, becomes so relevant and important for identity formation and also discipleship. Chryssochoou (2003:225) describes identity as 'a cyclical process constituted by three actions: knowing, claiming and recognising'. It is only through participation in the social world that individuals create a view about themselves and the world which forms their identity.

Identity amongst millennials, who might spend a large part of their lives in the cyberspace, has become more of a social representation than individual property. If identity amongst millennials is viewed more as a social representation rather than individual representation, then identity should not only be seen as an individual property from which actions and behaviours originate but it can also be a fruitful tool in understanding social phenomena. Thus, in the making of disciples, the Church is not the only actor in the forming of identity (or disciples), because the identity represents the relationship between an individual and 'others' whether real or symbolic, individuals or groups (Chryssochoou 2003:227). The social representation of the Church (her identity), how she thinks, speaks and presents herself (knowing, claiming and recognising), is of utmost importance in making disciples amongst the diverse group of millennials in Africa. Malan Nel (2015a:4) writes in this regard: "that "learning" and coming to terms with "our" own brokenness is almost a prerequisite for disciple-making churches'. The identity of the church as kerussein 'the called out' as disciple-maker is thus very important.

Chryssochoou (2003:228) continues to discuss identity as the relationship between the individual and the world according to the following three elements: an element of cognition (selfknowledge), an element of self-action and an element of other(s) actions. If the church recognises herself as an 'outsider', a 'heathen church' or a 'tax collector church', she will be able to think of those outside the church as implicit 'insiders' and determine the relationship with the 'others' (Nel 2015a:5). In this article, with the focus on Africa, the 'others' might refer to people similar or dissimilar to oneself, before oneself (ancestors), contemporary to oneself or after oneself (future generation). Understanding identity also as a social representation, we need to study the relationship that millennials, or the church establish with real or symbolic others, in order to understand the categories and identity concepts that are used to describe 'the other' and the world (Chryssochoou 2003:229). It is in this regard that Bosch (1991), writing about discipleship in Matthew, indicates the following important concepts by which the church, disciples and their mission is described:

the reign (basileia) of God (or of heaven), God's will (thelema), justice (dikaiosyne), commandments (entolai), the challenge to be perfect (teleios), to surpass or excel (perisseuo), to observe or keep (tereo), to bear fruit (karpous poiein), and to teach (disdasko). (p. 65)

Chryssochoou (2003:230), writing about identity formation with children, concludes that the relations to 'the other' determine the knowledge that children acquire about themselves to determine their identity. Although this is true about children, it is considered to be true of all people, the church and the millennials. The question must be: Is it the actions and representations of Christ or 'others' that guide the knowledge that the church and the millennials acquire about themselves? Which relationship with the 'other', whether the church, traditions or technology, is the most important to determine the identity of the millennials? Nel (1994:24) answers the identity question about the church as follows 'The church exists for the sake of the One who brought it into being'. It may be concluded that the disciple exists for the sake of the one who called him or her to discipleship.

\section{Discipleship}

From the vast majority of literature, it is clear that discipleship means different things to different people in different generations. The concept of a disciple is rooted in the verb manthanein, which literally means to focus your thoughts on something. Nel (1994:101) writes 'disciple implies the existence of a personal bond - a bond that determines the whole life of the individual'. According to this article, discipleship is understood as to live in a relationship with other people and the Triune God to discover our true identity and vocation. The statements of Jesus, 'I do nothing on my own' (Jn 8:28) and '... apart from me you can do nothing' (Jn 15:5) are very clear statements on his identity, which is defined by 'others' or rather in relationship with 'others' especially the Holy Other. Jesus has no ministry no purpose apart from the will or the relationship of the Father. The significance of Jesus's ministry is the fruit of his relationship and submission to the Father. In the same way, the mission of the disciples of Jesus Christ is impossible apart from their communion with him (Baker 2013:38). Disciples of Jesus Christ live with the specific calling of discipleship which is 'the process of following Jesus', put differently it is 'an art, 
skill, or craft'. Discipleship is not simply an internal condition of believers, but also involves the active manifestation of a relationship with Jesus Christ. The word discipleship does not appear in the Bible, but the concept is implied in the Great Commission to go make disciples (Shirley 2008:210).

\section{Discipleship and calling}

Discipleship, for most people, is closely related to the 'Great Commission' (Matthew 28:16-20). It is even called 'a manifesto' for the church, in the same way as the 'shema' (Dt 6) of the Old Testament. Bosch (1991:56-83) indicates that Matthew 28:18-20 must be read and interpreted against the background of the whole of Matthew's gospel and his community not to be misinterpreted. He further argues that Matthew views mission as disciple-making. Matthew views disciple-making as guidance to a community in crisis on how to understand and live its calling and mission (Bosch 1991:57). Much of our identity, who we are or will become, has to do with our calling. Malan Nel (2015a:1) describes discipleship and the making of disciples as a lifelong journey to rediscover and recover the fullness of our lives. Myers (2011:228) describes the goal of discipling to discover our true identity and our own true calling in God. Where people act in the name of identity like calling themselves disciples, they make claims about whom they are and to whom they relate. Claims like these are in itself an action upon the world. 'Identity claims represent positions that one has or seeks to achieve and simultaneously they describe the desired content of these positions' (Chryssochoou 2003:236). Discipleship will determine what kind of person I will be in the end. The church:

was called to be a community of discipleship, in which the apostles, by proclaiming the Word, baptising and celebrating the Lord's Supper, were to guide new believers to observe all that Jesus himself had commanded. (CWME 2012:para 2)

It is from these perspectives that this article wants to argue that identity, who I am or will become, is closely related to discipleship, especially within the African millennial generation of today. Being a disciple is about being obedient, not successful. In a success driven world, it is important to present 'other' Kingdom values to millennials in Africa. Millennials must understand and experience themselves as a gift from God to (South) Africa and the world (Myers 2011:235).

Discussing identity and discipleship amongst the millennials, it is important to acknowledge the dichotomies of the modern and African worldviews. In the modern world, there is a distinction, almost a separation, between the spiritual worlds or sacred revelation, where people know through experience (believing) and the real world, where people hear, see, feel and touch. In the modern world, scientific observation allows to know with certainty while the spiritual world is a personal and private place (Myers 2011:6). The traditional worldviews, as found in the Bible and in Africa, is a holistic worldview with the material and spiritual world, interrelated in a unified whole. In the traditional worldview, the unseen world of high religion is occupied by gods that should not be troubled (Mbiti 1991:60-81; Nurnberger 2007:19-55). In Africa, the unseen and the seen world are interrelated through ancestors, shangomas, spirits and others who have access to both worlds. In a modern world, the unseen high religion and the seen physical world is recognised but the world of folk religion is not recognised or addressed. Hiebert (in Myers 2011:7) calls this 'the excluded middle'. The question is what kind of disciples are made in Africa if modernisation and the Western church no longer believe in ancestors, spirits, demons and other unseen characters. The impact of this 'excluded middle' then creates a blind spot in making disciples within a traditional context of Africa. From a Biblical perspective, the physical world is never disconnected or separated from the spiritual world and the rule of God. The incarnation of the Lord Jesus Christ into this world is the best proof that the physical and the spiritual world may not be separated (Myers 2011:8). It is important to notice that the Biblical worldview with only one God differs from the traditional Africa worldview, which is dynamistic or animistic (Nurnberger 2007:16, 21). To address the issue of how to relate to the 'other', the Gospel-as-word addresses the question of truth in the spiritual world, regarding the 'excluded middle' (the question of power) is addressed by the Gospel-as-sign, and in the physical world the Gospel-asdeed addresses the question of what works (Myers 2011: $8-10)$. The implication for disciple-making is that it is not only about preaching the gospel but also believing and living the gospel.

From a post-modern and African traditional perspective, it seems as if Christians have the same struggle as the Christians in Matthew, as described by Bosch (1991:58). Christians today do not necessarily understand themselves 'as being members of a different religion over against' secularism, Western culture and African traditions but see themselves primarily as a renewal movement within, just as the Christians in Matthew once did, wanting to transform Judaism from within. According to the author, it is this inability or maybe unwillingness to make the final and absolute break with an old life and commit to discipleship of Jesus Christ that contributes to the identity crisis in the church and amongst many millennials in Africa. Within some of the African Initiated/Independent Churches (AICs), the Old Testament is used to indicate that Christ is the 'fulfilment' of African beliefs and, from the New Testament perspective, he is viewed as one of the ancestors. ${ }^{3}$ It is important to note that Matthew is using the Old Testament to prove Jesus as Messiah and as witness against the Jewish theologians of his day and their use of Scripture through the titles, he applied to Jesus such as Immanuel, Christ and Son of David (Bosch 1991:59). Van den Berg (2009:341) writes 'the recognition of grace does not justify remaining in a sinful way of life. It entails moving to a whole new life. The call entails discipleship; it entails moral change', it entails conversion on a daily base. 
This brings us to the close and important relationship between evangelism and discipleship. 'Evangelism is mission activity which makes explicit and unambiguous the centrality of the incarnation, suffering, and resurrection of Jesus Christ without setting limits to the saving grace of God' (CWME 2012:para 80). Malan Nel (2015a:3) understands disciplemaking as the core of evangelising. Bosch (1991:10-11) helps us to rediscover that mission is God's 'yes' and God's 'no' to and in this broken world. He continues to refer to evangelism as one of the 'essential dimensions' of the mission. Evangelism always aims at a response to a present gift (of life). Therefore:

the personal enjoyment of salvation never becomes the central theme in Biblical conversion stories ... it is almost incidental and secondary. It is not simply to receive life that people are called to become Christians, but rather to give life. (Bosch 1991:414)

Malan Nel (2015a:3) describes the decisions that need to be made as a decision for a commitment to a life of discipleship and obedience and not a decision to wait on heaven. Where identity is influenced through relationships with 'others', discipleship is to be a servant of life to 'others'.

Another important relationship between evangelism, discipleship and church was already indicated in the discussion on identity. There is no other agent that can make disciples of Jesus Christ, except the church. It is also true that 'Evangelism may never be given a life of its own, in isolation from the rest of the life and ministry of the church' (Bosch 1991:412). To make disciples is not just one component of the church, but it is a guiding value that permeates every ministry area (Shirley 2008:208). It seems as if the church in many instances attend to evangelism and discipleship in an unrelated manner (Nel 2015a:3). It must be clear that there is a difference between evangelism and disciple-making but they are interdependent. Unless a church makes 'committed disciples, all the evangelism, teaching, fellowship, worship, and ministry will be empty and powerless' (Shirley 2008:212).

\section{Millennials}

An important aspect of making disciples, focussing on the millennials in Africa, is the fact that the millennial generation in Africa is one of the largest (millennial) populations in the world and the least researched. Counted and Arawole (2016:7) describe Africa's more than 200 million millennials between 15 and 24 years of age as the largest population in the world. In most articles, the millennials are described from an American and or Western perspective. The following four generations from the American society are described namely, the silent generation (1930-1945), the baby boomers (19461964), generation $X(1965-1979 / 1981)$ and the millennials (1980-2000) (DeVaney 2015:11). The generations are defined by great historical happenings that influenced the society. Within the African context, we can also divide different generations around the different stages of colonialism on the Africa continent. The so-called 'silent generation' (1930-1945) in Africa may be known as the colonised generation, who was ruled by 'strangers' from the west. The baby boomer generation (1946-1964) in Africa started the fight against colonialism. This period is known for the $300-400$ instances of political violence in more than 40 states in Africa. The baby boomers in the rest of the world experienced 'economic prosperity and the growth of the suburban middle class' (DeVaney 2015:11). Africa's generation X (1965-1981) experienced the decolonisation of Africa and the first African regimes (Meiring 1987). The (South) African millennials are in many instances the first 'born free' generation in Africa after colonisation. In many instances, the African millennials do not see themselves as 'born free'.

It is indeed a question whether it is possible to deal with the generation theory in a traditional worldview such as Africa, with clear set of authoritative roles within the clan or tribe. Within the clan or tribe, every member has a defined status and role - '... any transgression of these roles would upset the balance in the system, [therefore] authority is fundamental for survival, health and prosperity' (Nurnberger 2007:10). Norgaard (2015:233) remarked that 'It seems as if the born free label is more aspirational than real'. He continues that young South Africans indeed hold unique attitudes, values and opinions, but these are easily mapped or uniformly associated with the millennials. 'At the aggregate level, at least, born free South Africans do not possess distinctive views on their generation's identity' (Norgaard 2015:235). One of the characteristics of the 'born free' or millennial generation is not a 'finished generational identity, but rather an ongoing and vexed process of identity formation' (Norgaard 2015:236). The 'born free' name has been thrust upon the African millennials rather than one that has developed spontaneously. Vincent Maphai, the former Executive Director of Corporate Affairs at South African Breweries (SAB), says:

the notion of 'born frees' is a commercial and commercialized term we use in the marketing departments ... At South African Breweries (SAB), we used this all the time as part of our key marketing demographic ... The 'born free' concept is a muddy concept. It doesn't catch a reality, it creates a reality. (Norgaard 2015:237)

This is a clear indication that names or identity is created through different relationships for different purposes. If identity is known, claimed and recognised it also creates reality. Keum (2013:4) writes: 'Spirituality gives the deepest meaning to our lives and motivates our actions'. Focussing on discipleship it might be stated that Africa as continent is in surge of a 'new' spirituality. It is not only the millennials that are developing their own new identity, the identity and spirituality of the Africa continent are in fluctuation with the influences of modernity and postmodernity. Therefore, it is no longer possible to talk about an African identity or spirituality. We must rather talk about identities and spiritualities. Nurnberger (2007) elaborates:

At least in urban areas, the current scene is a chaotic mixture of such elements. Interaction guarantees that there are no 'pure' forms of spirituality, that great differences exist amongst them, that they are all in flux, that real life is characterised by a vast field of transitions, amalgamations and overlaps. (p. 9) 
Many African millennials find themselves caught-up in traditional beliefs through rites of passage that older generations expect them to perform especially in sickness, child birth, initiation, marriage, death, etc. They are also the generation that experiences the full impact of modernism, since we find that many of them are the first or only the second generation who have tertiary education. To complete the picture they are also the African generation that are mostly influenced by postmodern thoughts through the electronic media. As the first 'born-free' generation influenced by post-modernism, they have a great 'quest for enjoyment' that exploits all boundaries. Then again, for contextual reasons many of those who are millennial parents leave their children to be raised by grandparents ${ }^{4}$ who might still be very traditional and staying in the rural areas. In the lives of many millennial Africans there is a negativity towards Christianity because of their cultural experience or belief that Western culture, which is directly related to Colonialism and based on Christianity, is unjust and corrupt. (Knoetze 2016:5)

Up to now, research has focussed on millennials as students (Crappell 2015:40). Focussing on discipleship in Africa, it is important that we must deal with the millennials also as millennial parents. This implies new trends in family structures, economic situations and more importantly communication, which may have a big impact on an approach to do discipleship (cf. Crappell 2015:40). Although the millennials in Africa is also known as a generation of 'digital natives', it is also true that many of them, especially in rural areas, have never seen or used a computer. In Africa, 'digital natives' rather refer to mobile and smart phones (cf. Counted \& Arawole 2016:2-3).

Many millennials in Africa live in poverty because of the socio-historic and economic circumstances such as the lack of (proper) education or education opportunities as well as the lack of job opportunities. In spite of this, the author believes that the political, and therefore, socio-economic future of Africa is already, and will in future, be determined by the millennial generation, examples in this regard are the Arab Spring in Egypt 2011 and the student revolts in South Africa in 2015-2016 about student fees at universities. Another unique characteristic of the African millennials is that they are mostly very active in the church although not in church leadership. Although the millennials in Africa is in an ongoing process of interpretation, it seems that many are still relating to some African traditional beliefs, which contribute to their identity. From a discipleship perspective in postmodern Africa, we need to take note of Evans (2015:4) saying 'Postmodern epistemology necessitates respect for, and celebration of, particularity and "otherness" in all dimensions of human life, from race and ethnicity to gender, religion and culture'.

\section{Millennials as disciple-makers}

Before attending to the question: What are the identity perceptions used in viewing the millennials and the church? It needs to be clarified, who is making disciples? Just like in
Biblical times, there are different Rabbi's. Looking at the millennials worldwide, it seems they are the great inventors regarding communication in this day and age. For instance, the founders of the following companies were all millennials: You-Tube, Facebook, Twitter, Groupon, Foursquare, Instagram and Tumblr (cf. Saratovsky \& Feldmann 2015 in DeVaney 2015:13). Taking the development of these social companies into account, it is clear that the millennials are actually discipling the world. The two examples from North and South Africa already mentioned; the Arab Spring in 2011 and the student riots in 2015-2016 illustrate how the millennials are discipling the world (see also Nel 2015b), with their own message of freedom. Especially in Africa this is not only happening on a national level but also at a local household level where many millennials help their parents and other elders, for example, to use and adapt to the electronic media and electronic banking system. Thinking about discipleship from the church point of view, it is important to realise in Africa most of the millennials are involved in local churches. Saratovsky and Feldmann (2015) (in DeVaney 2015:13) acknowledge that millennials are motivated as much by their personal relationships and human connections as they are by the influences of their technological skills and the social media. For these reasons, the church needs to look differently at the millennials not only as objects to disciple but also involve them as subjects to make disciples. The involvement of millennials and the social media will eventually help to determine a new openness and accessibility which would have an influence on the kind of church we are going to be.

To reach out to and to involve millennials in the discipleship of the church, the following steps may be followed: The first step is to provide access to God's story in the community to enable millennials, to take an active role in the development of a new identity and discipleship roles. The second step is to be transparent about discipleship and allow millennials the ability to access information on how the church affects the community and how it raises and spends money (stewardship). The third step is to develop engagement platforms within the church and the community that are social in nature and allow for greater discussion both online and offline. The fourth step is to create an environment in which millennials (people) can discover their own story in the God story and become more aware that they are living God's story.

\section{Access to God's story}

Earlier it was indicated that the identity of the millennials and the church in Africa are in a flux. Al-Abdin, Dean and Nicholson (2016) use:

history, happening, and hopes narratives to show that the self in a liminal period of flux is referent to history and hopes and proposes a notion of a transitional self that incorporates this observation of reference to past and future. (p. 45)

Although the identity of the church is only to be found in the God story there are some deviations. Focussing on Africa (what is happening) we find that some of the AICs are 'only 
one step removed from traditional African religious reality' (Oduro et al. 2008:10) which definitely influence the way they are being church. In relation to the Mainline Missionary Churches (MMCs), many African millennials experience the MMC's Christianity as negative because their cultural experience is not recognised and that Western culture, which is directly related to colonialism (Bosch 1991:226-230) and based on Christianity, is unjust and corrupt (history). It is from these perspectives that the church needs to answer the question: what kind of church are we going to be (hope and future)? It seems that regarding the identity of the church, she needs to rethink her social representation and relationship with different social groups ('others'). Norgaard (2015:238239 ) indicates how the millennials prefer to craft their own names to names given by their parents or other institutions in society. In creating their own names, they establish their relationship with institutions and their future. As millennials live in a global society, they might not be satisfied with any of the above relations of the church or even relating to the names of the church. The church must reclaim her identity by knowing the Trinitarian God, claiming her relationship (koinonia) with him and recognise him in everything she does. Looking at the future, it might include rethinking the name of different church denominations.

Answering to the hope narrative, there needs to be a serious focus on the millennial generation as the largest group of people in Africa and the world. From the perspective of the identity perceptions of the church, the millennials can still be seen as a marginalised group:

Discipleship with the marginalized at the centre reclaims and redefines their marginalized identity as equals with the risen Christ. Christianity to the marginalized must theologically resonate with people's deepest places of hurt. They must see, hear and know their story in God's story. We are all made in the imago dei, the image of God - the same God who breathes life into each one of us. As disciples of Christ, the identity of Imago Dei is the greatest equalizer against hierarchies of oppression. (Roberts 2014:192)

The main concern is how does the church, with her different perceptions on the identity of the millennials, involve them in the discipleship of the church? What is the identity of the millennials in the church? How are those who are part of the church viewed? Senter's (2001) book: 'Four views of youth ministry and the church' might help in this regard: Are they included in the total ministry of the church (inclusive congregational approach)? Or, does the church have a specialised ministry preparing the millennials to be become part of the ministry of the current church (preparatory approach)? Or, are the millennials viewed as mission objects even those who are part of the church (missional approach)? Or, are the millennials viewed as a strategic ministry? They are disciples because they will be the church of the future. Thinking about the identity of the millennials inside and outside, the question for the church remains: How does the church give the millennials access to the God story through spiritual leadership? Describing the millennials as 'digital natives' with a focus on relationships, the church needs to ask questions related to e-churches and even e-discipleship programmes? This will be further discussed at platforms of engagement.

\section{Be transparent about discipleship}

From the 'outside' in many instances, the name of a denomination is linked to a specific ministry or understanding of church (knowing), although it might not be experienced ministry (claiming) by the denomination's members. For example, when people hear the name Dutch Reformed Church, Apostolic Faith Mission, Zion Christian Church, et cetera, members and non-members may have totally different even opposite recognitions of the ministries of these denominations. If the church wants to address the millennial generation, she has to give attention to her identity through the three actions of knowing, claiming and recognising (Chryssochoou 2003:225), which ask for much more transparency regarding societal relationships and the impact on society of the different ministries as well the way resources are gained and spend.

In discipling, when some millennials are not yet part of the church's outreach, the church must make use of millennial members with their knowledge and skills to make the church more transparent in a global world. Although discipleship or evangelisation will be done from a specific denomination, the focus may never be church growth but the growth of the Kingdom of God. Evangelisation and discipleship has to do with accessing a relationship with the Trinitarian God and stewardship. For this reason transparently about the cost of discipleship must not be shunted away, but it must be known, claimed and recognised in the lives of the disciple-makers, especially from a rich spiritual continent like Africa.

\section{Developing platforms for engagement}

Discipling people implies that we meet them in the spaces and platforms where they are. Describing the millennials as 'digital natives' with a focus on relationships, it is obvious that the millennial disciples of Christ are the best to make disciples of those millennials not yet part of the church. They belong to the same global culture, speak the same global language from their own unique contexts and enrich each other's lives. Understanding the influence of the millennials on the future of the church in (South) Africa, the church must embrace the multiple and often contradictory, identities of the millennials (Norgaard 2015:244).

The church will benefit in developing platforms for engagement inside and outside the church, both online and offline. The church in Africa needs the input of the millennials to create 'new' sacred spaces on electronic media for millennials from the rural areas. On the contrary, sacred places need to be created for urbanised millennials in nature. Thinking from the holistic African worldview, the church in Africa reaching to the millennials needs to ask important positive and negative questions related to e-churches and even e-discipleship programmes. Noticing 
the 'remix of social activism and theology' (Nel 2015b) amongst the millennials, the church needs to contribute and participate on these platforms the millennials had already created. Again, this is a good example how the millennials are discipling the world and the importance to bring the millennials from the margins of the being of the church to the centre.

\section{Relating to the God story}

Malan Nel (2015a:9-10) has a long and insightful discussion on individuation and individualisation. He makes much of the importance of community 'umuntu ngumuntu ngabanye! (isiZulu for "humans are humans through other humans" with reference to "interdependency"' (Nel 2015a:9) and 'I am because and only when we are' (Nel 2000:77-97). According to the researcher's own understanding of Christian discipleship and identity, this community is only of value if it is a community belonging to God in Jesus Christ (1 Jn 1:3). Therefore, the understanding of 'I am and you are, because He (God) is', is according to the author's understanding an important correction on the African perspective of 'ubuntu'.

Chryssochoou (2003:227) describes identity as the way in which we relate to ourselves and the world we live in. In being a church in Africa, it is important for the church to engage and to listen to the Africa millennials, to understand how they see their own identity in their relation with God within and outside the church. It might just be possible that the church discovers a 'new pool' of disciples that will enrich the identity of the church.

\section{Conclusion}

There are different views on the millennials in Africa from different perspectives. The question this article attended to is: What are the identity perceptions used in viewing the millennials and the church? This article concludes that while in many instances the church views the millennials as objects of discipleship, they are actually very important subjects of discipleship. The church in (South) Africa will benefit in different ways if they recognise the gifts and faith of millennials. From the research, it is clear that the millennials play a 'natural' leadership role in the world more specifically through their development of communication platforms. The millennials in the (South) African context play even a bigger leadership role, that is, almost a diaconal discipleship role where there are still a majority of illiterate people from other generations that need, for instance, help in the field of electronic transfers of money mostly in the rural areas via mobile phones. When identity and transparent discipleship give access to the God story through different platforms millennials relate to and realise they are participants in the God story, the question about identity perceptions of millennials might be answered with more clarity of hope. Millennials relating and participating in the God story making disciples will realise 'surely I am with you always, to the very end of the age' (Mt 28:20).

\section{Acknowledgements}

\section{Competing interests}

The author declares that he has no financial or personal relationships that may have inappropriately influenced him in writing this article.

\section{References}

Adogbo, M.P., 2005, 'Methodological problems in the study of African traditional religions', Journal of Theology for Southern Africa 122, 76-83.

Al-Abdin, A., Dean, D. \& Nicholson, J.D., 2016, 'The transition of the self through the Arab Spring in Egypt and Libya', Journal of Business Research 69, 45-56. https:// doi.org/10.1016/j.jbusres.2015.07.019

Baker, H. 2013 'The place of mission in Johannine discipleship: Perspectives from the motif of agency', Journal of Spiritual Formation \& Soul Care 6(1), 38-45.

Bosch, D.J., 1991, Transforming mission. Paradigm shifts in theology of mission, Orbis Books, New York.

Chryssochoou, X., 2003, 'Studying identity in social psychology. Some thoughts on the definition of identity and its relation to action', Journal of Language and Politics 2(2), 225-241. https://doi.org/10.1075/jlp.2.2.03chr

Commission on World Mission and Evangelism (CWME), 2012, Together towards life: Mission and evangelism in changing landscapes, viewed 16 March 2015, from http://www.oikoumene.org/en/resources/documents/commissions/mission-andevangelism/together-towards-life-missionand-evangelism-in-changing-landscapes

Counted, A.V. \& Arawole, J.O., 2016, “"We are connected, but constrained”: Internet inequality and the challenges of millennials in Africa as actors in innovation' Journal of Innovation and Entrepreneurship A Systems View Across Time and Space 5, 3. https://doi.org/10.1186/s13731-015-0029-1016

Crappell, C. 2015, 'Dealing with millennial parents', American Music Teacher, December/January 2015/2016, Professional Resources: NCTM, pp. 40-43.

DeVaney, S.A., 2015, 'Understanding the Millennial generation', Journal of Financial Service Professionals 69(6), 11-14.

Du Toit, C.W., 2004, 'Technoscience and the integrity of personhood in Africa and the West: Facing our technoscientific environment', in C.W. Du Toit (ed.), The integrity of the human person in an African context: Perspectives from science and religion, pp. 1-46. Research Institute for Theology and Religion, University of South Africa, Pretoria.

Evans, A., 2015, 'Aspects of child evangelism and youth ministry in South Africa in the postmodern context of globalism, pluralism and current scientific knowledge', Scriptura 114(1), 1-9. https://doi.org/10.7833/114-0-1042

Kabasele, F., 1991, 'Christ as ancestor an elder brother', in R.J. Schreiter (ed.), Faces of Jesus in Africa, pp. 116-127, Orbis Books, New York.

Keum, J. (ed.), 2013, Together towards life. Mission and evangelism in changing landscapes, World Council of Churches Publications, Geneva.

Knoetze, J.J., 2016, 'African Millennials and Missional Diaconate as Transformational development to God's glory', Unpublished Paper Delivered at IAMS Conference 2016.

Mbiti, J.S., 1991, Introduction to African Religion, 2nd edn., Heinemann Publishers, Johannesburg.

Meiring, P., 1987, Afrika, die hamer, die kruis en die sekel, De Jager-HAUM uitgewers, Pretoria.

Myers, B.L., 2011, Walking with the poor. Principles and practices of transformational development, Orbis Books, New York.

Nel, M., 1994, Who are we? Understanding and finding identity in the local church, Halfwayhouse, Orion.

Nel, M., 2000, Youth ministry: An inclusive congregational approach, Design Books, Centurion.

Nel, M., 2015a, 'Imagine-making disciples in youth ministry that will make disciples', HTS Teologiese Studies/Theological Studies 71(3), Art. \#2940, 1-11.

Nel, R., 2015b, 'Remixing interculturality, youth activism and empire. A postcolonial theological perspective', Missionalia 43(3), 545-557. https://doi.org/10.7832/43-3-124

Norgaard, S., 2015, 'Born free? Names, identity, and identity-formation', Bulletin of the National Library of South Africa 69(2), 233-244.

Nurnberger, K., 2007, The living dead and the living God, Cluster Publications, Pietermaritzburg.

Oduro, T., Pretorius, H., Nussbaum, S. \& Born, B., 2008, Mission in an African way A practical introduction to African instituted churches and their sense of mission Christian Literature Fund, Wellington.

Roberts, J.E.B., 2014, 'Discipleship with the marginalized at the centre', International Review of Mission 103(2), 189-199. https://doi.org/10.1111/irom.12056

Senter, M.H. (ed), 2001, Four views of youth ministry and the church, Zondervan Publishing House, Grand Rapids, MI.

Shirley, C., 2008, 'It takes a church to make a disciple: An integrative model of discipleship for the local church', Southwestern Journal of Theology 50(2), 207-224.

Van den Berg, M.L., 2009, 'Bonhoeffer's discipleship: Theology for the purpose of Christian formation', Calvin Theological Journal 44, 333-350.

Wright, C.J.H., 2006, The mission of God. Unlocking the Bible's Grand Narrative, InterVarsity Press, Downers Grove, IL. 